\title{
Environmental innovations and firms' organizational changes: What kind of complementarity? Evidence from French industrial firms
}

Danielle Galliano and Simon Nadel

\section{(2) OpenEdition}

\section{Journals}

Electronic version

URL: https://journals.openedition.org/rei/7600

DOI: $10.4000 /$ rei.7600

ISSN: 1773-0198

Publisher

De Boeck Supérieur

Printed version

Date of publication: 15 December 2018

Number of pages: 37-71

ISBN: 978-2-8073-9207-6

ISSN: 0154-3229

\section{Electronic reference}

Danielle Galliano and Simon Nadel, "Environmental innovations and firms' organizational changes: What kind of complementarity? Evidence from French industrial firms", Revue d'économie industrielle [Online], 164 | 4e trimestre 2018, Online since 02 January 2022, connection on 03 June 2022. URL: http://journals.openedition.org/rei/7600 ; DOl: https://doi.org/10.4000/rei.7600 


\section{ENVIRONMENTAL INNOVATIONS AND FIRMS' ORGANIZATIONAL CHANGES: WHAT KIND OF COMPLEMENTARITY? EVIDENCE FROM FRENCH INDUSTRIAL FIRMS ${ }^{1}$}

Danielle Galliano, Institut National de la Recherche Agronomique INRA UMR 1248 AGIR 24, chemin de Borde-Rouge CS 52627 F-31326 Castanet Tolosan Simon Nadel, Université de Lille, UMR 8019 CLERSE, F-59000 Lille

Keywords: Eco-innovation, environmental innovation, organizational changes, complementarity, French industry.

Mots clés: Éco-innovation, innovation environnementale, changements organisationnels, complementarité, industrie française.

\section{INTRODUCTION}

The literature defines an environmental innovation, or "eco-innovation" as a product, production process, service, management or business method that is new to the organization, and which results, throughout its life cycle, in reducing environmental risks, pollution and other negative impacts of resource use compared to relevant alternatives (Kemp and Person, 2007, Van den Bergh et al., 20II). An eco-innovation is therefore, by nature, a standard innovation that generates an environmental benefit. It is specified by its

I This work was supported by the French LABEX "SMS: Structuring social worlds" (ANR-II-LABX-oo66) and the PSDR4 Program (INRA/Conseil Régional Occitanie). 
necessary embeddedness, either on a technology (in the case of a product or process environmental innovation), or on an organizational arrangement, in the case of an organizational environmental innovation (Debref, 2016; Galliano and Nadel, 20I5; Rennings, 2000; Rennings et al., 2006; Horbach et al., 2013; Mazzanti and Zoboli, 2008). The adoption and diffusion of environmental innovations are then essentially marked by complementarity processes that embed eco-innovations within other innovations, whatever their nature (Antonioli et al., 20I3; Hottenrott et al., 2016).

The literature on complementarity has highlighted the existence of strong links between changes in a firm's organization, technological practices and innovation processes (Milgrom and Roberts, 1990, 1995; Bocquet et al., 2007). The fundamental idea underlying the concept of complementarity is that, in a changing environment, technological choices, organizational practices and a firm's structure must evolve coherently. Thus, success in implementing the innovation then depends on its interaction with the changes in a firm's organization. This question is particularly relevant to environmental innovation and to whether its expected environmental benefits will be achieved.

So far, the literature has focused on firm-level determinants of ecoinnovation, on the one hand, and, on the complementarity between two practices, when an eco-innovation is adopted, on the other. In line with Rennings' seminal paper (2000), a first set of works on eco-innovation has helped to better identify the microeconomic determinants of eco-innovation (Horbach et al. 2013; Del Rio et al., 2015; Frondel et al., 2007; Galliano and Nadel, 2015; Horbach, 2008; Hojnik and Ruzzier, 2016; Barbieri et al., 2015, Alonso Ugaglia et al., 20I6). A second set of literature has focused on complementarities between two practices when an eco-innovation is implemented, especially by focusing on the effects of complementarity on environmental productivity (Hottenrott et al., 20I6; Antonioli et al., 20II; Gilli et al., 20I4). However, to our knowledge, no study has systematically analyzed the foundations of complementarities and intra-organizational processes that support eco-innovation. In terms of public policy, gaining insights into these processes seems key to better understanding the mechanisms that promote the development of innovations with environmental benefits.

The objective of this paper is to analyze the nature and degree of complementarity between environmental innovations and technical or 
organizational innovations in order to evaluate the respective influences of the various forms of innovation and change on a firm's environmental performance. This research seeks to contribute to a better understanding of how businesses respond to contemporary environmental issues, particularly those related to firms' environmental performance. Beyond a global highlight of the nature of innovations that support ecoinnovation, we aim to examine more closely two dimensions that are given little attention in the literature. First, we intend to study complementary processes between eco-innovations and organizational innovations, which are often considered minor compared with technical innovations. Second, we analyze the issue of complementarity depending on the environmental impact of innovation ( $\mathrm{CO}_{2}$ reduction, reducing pollution, recycling, etc.) in order to shed light on the nature of complementarity between each kind of environmental impact and innovations within a firm, and to evaluate the influence of sectoral embeddedness and industrial structures in these complementary processes.

The analysis of complementarity is tested using the French Community Innovation Survey 2008 (CIS 2008), which provides information on the innovation behavior of French industrial firms from 2006 to 2008. The database provides information not only on product, process, organizational innovations, but also, for the first time in Europe, on environmental innovations.

In line with the "adoption approach" and Galia and Legros' (2004) methodology, we use bi-probit models to analyze complementarity processes at work in French industrial firms. This empirical strategy makes it possible to highlight the interaction between the joint adoption of two practices (environmental innovation vs. technical or organizational innovation). To our knowledge, this method has never been used for analyzing environmental innovations. This method is relevant and appropriate to our objective of analyzing, in a systematic way, the complementarity between different forms of innovation within a firm.

This paper is structured in five sections. The following section presents our theoretical framework. Section 3 presents our strategy to establish complementarity relationships, data and variables in the model. Section 4 presents the results, and the last section concludes the paper. 


\section{COMPLEMENTARITY AND ORGANIZATIONAL CHANGES IN ECO-INNOVATION PROCESSES}

The concept of complementarity emerged in the literature on innovation and the economics of organization, following Milgrom and Roberts' seminal works (1990, 1995). By definition, two activities are said to be complementary "if the profit or value created by doing both at the same time is greater than the sum of individual profits from doing one or the other" (Milgrom and Roberts, 1997). The idea underlying the concept of complementarity is that, as Chandler pointed out in a historical perspective (1962) - a firm's managerial and technological practices (i.e., choices in terms of innovation), and its structure are linked and must evolve in a coherent fashion, in a changing environment. Milgrom and Roberts (I990) also introduced the concept of supermodularity, which is associated with the optimization of a complementary function, and which includes strategic and organizational factors into the objective function of the firm, in addition to the classical capital and labor factors (Milgrom and Roberts, 1995; Milgrom and Roberts, I990). This approach has been used in several studies that have highlighted the strategic and organizational dimensions of complementarity in different contexts (Topkis, 1998; Bocquet et al., 2007; Laursen and Mahnke, 200I; Laursen and Foss, 2003; Hottenrott et al., 20I6; Leiponen, 2005).

The literature on complementarity has mainly focused on questions related to firms' performance (Ballot et al., 20I5). Yet, since this approach considers that technological choices, organizational practices and firms' structures must evolve coherently, that the adoption of innovations must be associated with organizational changes. The complementarity between organizational changes and innovation is highlighted in empirical works conducted in 6 EU countries (Evangelista and Vezzani, 20I2), in Norwegian firms (Sapprasert and Clausen, 20I2), UK firms (Battisti and Stoneman, 20I0) and Spanish firms (Hervas-Olivier et al., 2012).

With regard to organizational change, it is understood as any change in the distribution of powers, skills, information, or in the lines of communication inside the firm (Greenan, 2003; Brynjolfsson and Hitt, 2000), and in its external relations (Benghozi, 200I; Battisti and Stoneman, 2003). More widely, an organizational change refers to a change in the organization 
of production, in the organization of labour, and in the relations between the firm and its external partners. Various authors point out, in particular, that, while firms adopt new technologies, organizational changes are related to a more highly skilled workforce, a "flattening" of the hierarchical structure, delegation of responsibilities and decentralization of decision making (Greenan, 2003; Antonioli and Mazzanti, 2009), as well as to different forms of change in a firm's external relations (Galliano and Orozco, 2013). Within this framework, the literature highlights that such organizational changes associated with the adoption of innovations can result either from a planned strategy, or from a firm's adaptive behavior (Hodgson and Knudsen, 2007; Galliano and Orozco, 2013). The theory of supermodularity (Milgrom and Roberts, 1990, 1995) involves the hypothesis of a planned (goal-oriented) organizational change through which the firm seeks to optimize its organizational, strategic and technology practices (Milgrom and Roberts, 1990; Bocquet et al., 2007).

A second framework is associated with an adaptive approach to organizational change. The relationship between innovation and organizational practices is analyzed within a theoretical framework in which organizational change is considered as an "endogenously induced change of organizational routines" (Becker and Lazaric, 2003). Consequently, in this framework of analysis of environmental innovation, a firm is seen as developing organizational skills "that improve responsiveness to sustainability challenges" (Wagner and Llerena, 20II). From this perspective, therefore, the adoption of environmental innovations goes hand-in-hand with changes in routines and skills involving environmental issues, which leads to the transformation of firm organization (Chen and Chang, 2013; Wagner and Llerena, 20II; Hart, I995; Sharma and Vredenburg, 1998).

A number of empirical studies on eco-innovation have examined the firmlevel determinants of adoption of environmental innovations and have highlighted the complementarity between organizational innovations and environmental innovations in various national contexts (for Italy, see Mazzanti and Zoboli, 2008; Germany, in Wagner, 2007 and a comparison France / Germany in Horbach et al., 2013) or in sectoral analyses (Rothenberg and Zyglidopoulos, 2007). Whatever the different sectoral or national contexts, the question of organizational change was mainly studied through three dimensions: the work organization and firm 
management, the production organization; and changes in firms' external relations (Horbach et al. 2012; Antonioli et al. 2013).

In terms of changes in work organization and management associated with firms' development of environmental innovations, most research has tended to bring to light the role of the manager (Wagner and Llerena, 2oII; Robertson and Barling, 2013), employee training (Horbach, 2008; Cainelli et al., 2012) and the involvement of the workforce (Delmas, Pekovic, 2013, Nadel, 2013) in the implementation of new environmental practices. The study conducted by Delmas and Pekovic (2013) has highlighted that a rise in environmental standards within firms was associated with higher labor productivity. The authors postulated that this growth of labor productivity resulted from an increase in the employees' engagement in their workplace. They showed that, in firms that are proactive on environmental issues, employees tended to receive more training and have better interpersonal contacts. Another study, conducted by Antonioli et al. (2013), pointed to complementarities between human resource management practices and organizational practices, such as High Performance Work Practices (HPWP), when the eco-innovation implemented is expected to reduce $\mathrm{CO}_{2}$ emission. According to the authors, the emergence of complementarities strongly depends on the sector in which the firms are embedded - those complementarities occurring only in the case of polluting industries, which are subject to strict environmental regulations (Antonioli et al., 2013; Lee et al., 20II).

Regarding the link between changes in production organization and environmental innovation, many studies emphasize the interaction between the introduction of environmental management systems (EMS) and the development of environmental innovations (Frondel et al., 2007; Mazzanti and Zoboli, 2008; Rehfeld et al., 2007; Wagner, 2008). Using data on Czech, German and Portuguese industrial firms, Antonioli et al. (2013) reveal complementary relationships between the development of new information technologies and the adoption of environmental innovations. They consider the development of environmental innovations as being part of an overall dematerialization and decarbonization strategy. This interaction between changes in the production organization and eco-innovation was confirmed by Horbach (2008), who, using the case of German industries, show that the link between the evolution of organizational structures and eco-innovations is stronger than that between organizational changes 
and standard innovations. Furthermore, Horbach et al. (2013) stress that a higher degree of production flexibility has a positive effect on the adoption of eco-innovations by French and German industrial firms.

As regards with the changes in firm external relations, they are also associated with the development of environmental innovations related to issues of industrial ecology and circular economy (McDonough and Braungart, 2002). These reconfigurations of interfirm relationships are linked to change in firms' relations with their territory, especially when they have adopted environmental innovations aimed at improving waste management and implementing recycling practices (Brouillat and Oltra, 20I2). We also note that some studies have provided more detailed analyses of complementarity according to the types of environmental impact, i.e., according to the different "output" of eco-innovation. Horbach et al. (2012) highlighted that in German industrial firms, the adoption of environmental innovations intended to reduce air pollution were complementary to changes in production organization, while a reduction of inputs and energy consumption was complementary to changes in the work organization. The adoption of environmental innovations aimed at improving pollution management (air, water, soil) is highly associated with changes in interfirm relationships.

On the whole, this emergent literature aims to show that firms can make more efficient use of the adopted technologies or practices if complementary forms of organizational design, or related technologies, are adopted at the same time (Hottenrott et al., 20I6).

\section{TESTING THE COMPLEMENTARITY BETWEEN TECHNICAL, ORGANIZATIONAL AND ENVIRONMENTAL INNOVATIONS}

The aim of this section is to propose a methodological framework to support the empirical test on complementarity between technical, organizational, and environmental innovations. In this section, we present our empirical strategy whereby we use bivariate probit models to reveal complementarity relationships. We then describe the dependent variables and the set of explanatory variables incorporated into the models. 


\subsection{Method and model}

The literature tends to distinguish two approaches to studying complementarity (Mazzanti and Zoboli, 2008; Gilli et al., 2014; Hottenrott et al., 2016): the "productivity approach" and the "adoption approach". The productivity approach is used when the objective is to study the complementarity between two elements on a performance indicator (such as productivity), on the basis of the construction and optimization of an augmented production function (Milgrom and Roberts, 1995; Bocquet et al., 2007; Gilli et al., 20I4). The adoption approach generally considers that a positive correlation between two activities is a relevant indicator of their complementarity (Arora and Gambardella, 1994; Arora, 1996). This second approach is the most appropriate for our analysis, in that we aim to highlight the nature and degree of complementarity between environmental innovation and technical or organizational innovation - not to study performance-related issues. Two estimation methods could be used in the adoption approach: the reduced form method, and the bivariate probit method. The "reduced form method", consists in analyzing complementarity on the basis of the correlation between two factors (Arora, 1996). According to Galia and Legros (2004), the key idea behind this method of calculation is that "a factor which has an effect on one variable will not be correlated with another variable unless the variables are complementary". The limitation of this method when studying complementarity lies in the fact that we could only test two variables simultaneously (Arora, 1996; Athey and Stern, 1998). The second method is used for testing the correlation between different variables conditional on a number of common explanatory variables (Galia and Legros, 2004). According to these authors, we consider that "complementarity creates a force in favor of positive correlation (or clustering) between two variables, even after controlling for observable, exogenous characteristics." The method we have pursued, tests complementarity using bivariate or multivariate probit models. This enables us to study the complementary relations between adopting environmental innovation and organizational and technical innovations with bivariate probits. With this approach, the existence of complementarities is confirmed if the hypothesis of noncorrelation of residuals is rejected (Galia and Legros, 2004; Laursen and Mahnke, 20oI). Once an environmental innovation is necessarily embedded either in a technology (for a product and process innovation), or in an organizational arrangement (in the case of an organizational innovation), the endogeneity inherent in the adoption of environmental innovations had 
to be taken into account in the analysis of the various types of complementarity. In order to overcome the endogeneity problems related to joint adoptions of different types of innovations, Wooldridge (2002, p. 623) suggests estimating binary choice models using bivariate probit models. This method makes it possible to take into account the interactions between the different types of innovation. This joint effect is captured by the interaction term. ${ }^{2}$ Therefore, if for example, an organizational innovation (or product/process innovation) and an environmental innovation are adopted in a complementary manner, there will be a high probability that a firm adopting one will also adopt the other. Using a bivariate probit model, we then consider the joint probability associated with the adoption of an organizational innovation (or product/process innovation) and an environmental innovation.

It is specified as follows (Greene, 2003):

$\left\{\begin{array}{l}y^{*}{ }_{11}=x_{11} \beta_{1}+\mu_{i 1} \\ y^{*}{ }_{12}=x_{i 2} \beta_{2}+\mu_{i 2}\end{array}\right.$

- With $\mathrm{E}\left[\mu_{\mathrm{i} 1}\right]=\mathrm{E}\left[\mu_{\mathrm{i} 2}\right]=0$,

- $\operatorname{Var}\left[\mu_{\mathrm{i} 1}\right]=\operatorname{Var}\left[\mu_{\mathrm{i} 2}\right]=1$,

- $\operatorname{Cov}\left[\mu_{i 1}, \mu_{i 2}\right]=\rho$

The two latent variables $\mathrm{y}^{*}{ }_{11}$ (probability of eco-innovation) and $\mathrm{y}^{*}{ }_{\mathrm{i} 2}$ (for example, organizational innovation) are explained by a linear combination of $\mathrm{x}_{\mathrm{i} 1}$ and $\mathrm{x}_{\mathrm{i} 2}$, respectively, and we observe variables $\mathrm{y}_{\mathrm{i} 1}$ and $\mathrm{y}_{\mathrm{i} 2}$ such that: $\mathrm{y}_{\mathrm{i} 1}=1$ and $\mathrm{y}^{*}{ }_{\mathrm{i} 1}>0$ and 0 otherwise (in the same manner), $\mathrm{y}_{\mathrm{i} 2}=\mathrm{I}$ if $\mathrm{y}^{*}{ }_{\mathrm{i} 2}>0$ and 0 otherwise. The firm is denoted $i(i, \ldots, n)$ and $x$ represents a vector of control variables related to the different dimensions of innovation adoption (firm's internal characteristics and external environment, see 3.4).

The bivariate probit model enables us to estimate the simultaneous occurrence of two events given the normal distribution of terms $\mu_{i 1}$ and $\mu_{i 2}$, and $\rho$, the correlation coefficient between the error terms. The model is fitted using the maximum likelihood method.

2 A simple probit model that estimate probability to eco-innovate have endogeneity issues, as soon as an eco-innovation is necessarly embedded in a technical or organizational arrangement. Results of such model cannot stress the joint effects related to technical (or organizational) and environmental innovation adoption. 
Empirically, the first objective is to test and compare the respective role of organizational innovation, product and process innovation, on the complementarity process with environmental innovation. To conduct a more in depth analysis of the role of organizational change, we will distinguish between changes related with production organization, work organization and in external relations. The second objective is to deepen this analysis by taking into account the type of environmental benefit generated by the eco-innovation, and the influence of sectoral embeddedness in these complementary processes.

\subsection{Presentation of data}

Our empirical analysis is based on individual data from two surveys conducted by the French National Survey Institute (INSEE): The Community Innovation Survey 2008 (CIS 2008) and the Annual Survey of Firms (EAE 2007). CIS 2008 is a mandatory declarative survey that provides information on the innovation patterns of firms with more than 20 employees, over the period 2006-2008. More specifically, it provides information on product, process, and on the different types of organizational changes implemented by firms (changes in the work organization, production organization or in external relations). It also gives information on the types of environmental innovations adopted by each firm, by distinguishing nine main types of eco-innovation (cf. Table I). This survey is combined with EAE 2007, which provides complementary information on firms and sectoral structural characteristics. The database consists of data on 4,686 firms that employ more than 20 employees, representative of the French manufacturing industry. Around half of all French industrial firms $(50.23 \%)$ reported having adopted at least one environmental innovation over the period ( $72.94 \%$ of all innovative firms).

CIS 2008 is the first to have introduced an environmental section. The decision of the statistical services of the EU Member States to introduce a new section on environmental innovation into the CIS survey reflects the growing political concerns about ecological issues but also an economic situation, associated with an increasing integration of environmental issues into firm's strategy. 


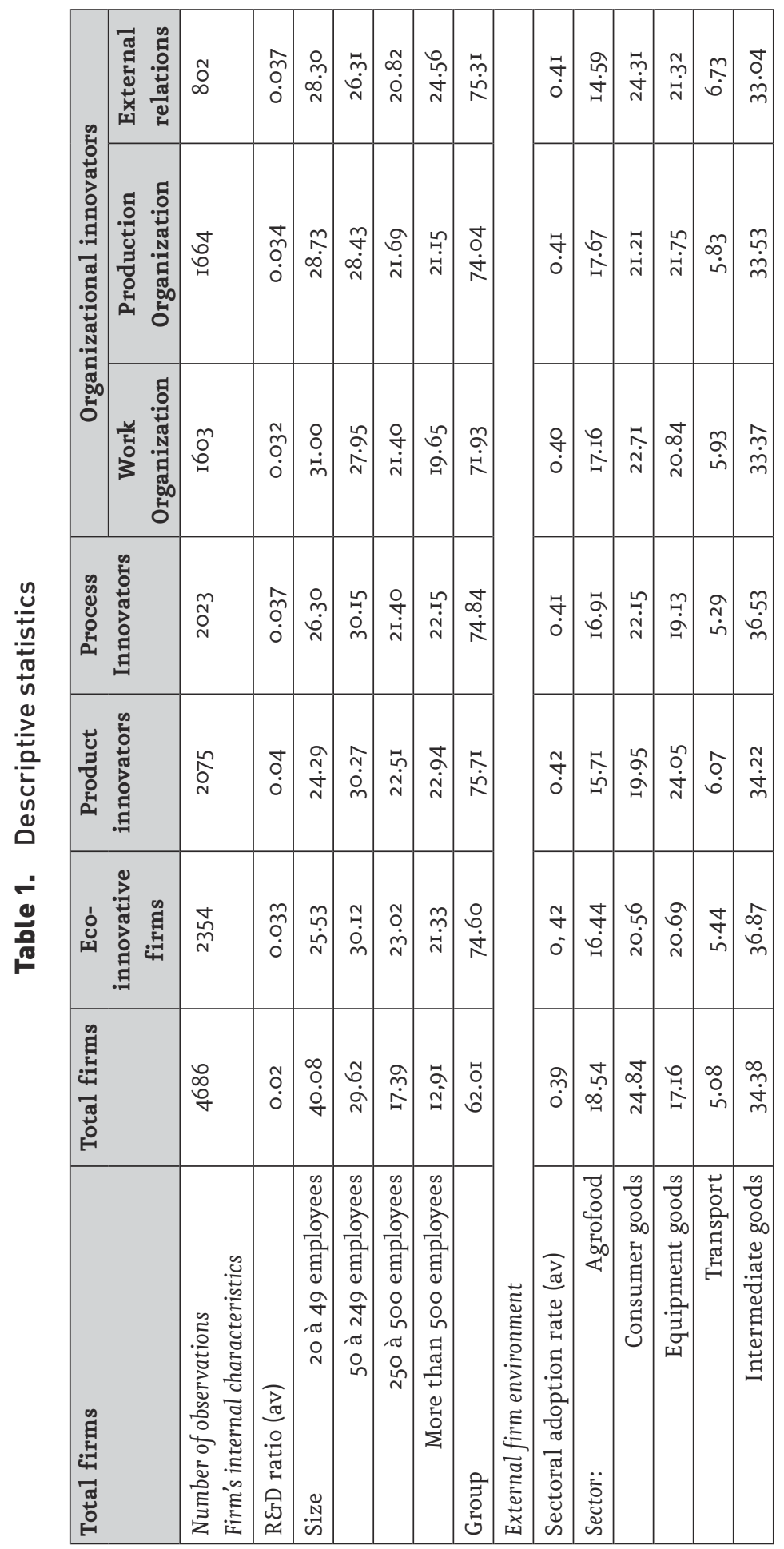




\begin{tabular}{|c|c|c|c|c|c|c|c|c|c|c|c|c|c|c|c|c|}
\hline $\begin{array}{l}\stackrel{+}{\hat{m}} \\
\dot{m}\end{array}$ & & 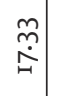 & $\begin{array}{l}\stackrel{0}{\stackrel{\leftrightarrow}{n}} \\
\stackrel{\leftrightarrow}{n}\end{array}$ & $\stackrel{\vec{f}}{m}$ & & $\begin{array}{l}\stackrel{R}{\dot{J}} \\
\text {. }\end{array}$ & $\begin{array}{l}\infty \\
0 \\
\dot{0} \\
\dot{\ddots}\end{array}$ & 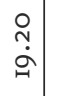 & & 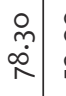 & $\begin{array}{l}\circ \\
\stackrel{0}{0} \\
\dot{\sim} \\
\end{array}$ & $\begin{array}{l}\stackrel{N}{\sim} \\
\dot{d}\end{array}$ & $\begin{array}{l}\stackrel{\sim}{\circ} \\
\dot{\forall} \\
\forall\end{array}$ & $\stackrel{\vec{n}}{\dot{\sim}}$ & 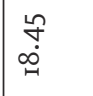 & $\begin{array}{l}\stackrel{2}{\grave{n}} \\
\dot{n}\end{array}$ \\
\hline $\begin{array}{l}\tilde{n} \\
\dot{m}\end{array}$ & & 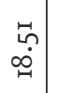 & $\begin{array}{c}\stackrel{9}{\hat{n}} \\
\hat{n}\end{array}$ & 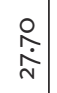 & & 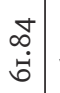 & $\begin{array}{l}\hat{f} \\
\dot{b}\end{array}$ & 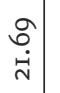 & & 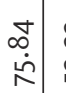 & $\begin{array}{l}\stackrel{N}{N} \\
\stackrel{N}{n}\end{array}$ & $\begin{array}{l}\dot{\infty} \\
\dot{\dot{b}}\end{array}$ & $\begin{array}{l}\infty \\
\stackrel{+}{+} \\
\dot{0} \\
m\end{array}$ & 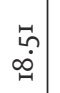 & $\stackrel{\stackrel{一}{m}}{\dot{\Xi}}$ & $\mid \begin{array}{c}n \\
\tilde{\infty} \\
\infty \\
\sigma\end{array}$ \\
\hline $\begin{array}{l}\tilde{n} \\
\dot{m}\end{array}$ & & $\begin{array}{l}\text { oे } \\
\dot{i}\end{array}$ & 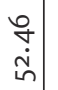 & 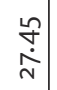 & & 苞 & 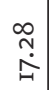 & $\begin{array}{l}\stackrel{\infty}{\stackrel{\overbrace{}}{i}} \\
\stackrel{\sim}{i}\end{array}$ & & $\begin{array}{l}\stackrel{a}{+} \\
\stackrel{N}{N}\end{array}$ & 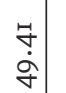 & $\begin{array}{l}\stackrel{n}{\sim} \\
\stackrel{\sim}{n}\end{array}$ & $\begin{array}{c}\dot{\infty} \\
\dot{m} \\
m\end{array}$ & $\stackrel{\circ}{\stackrel{\sim}{\sim}}$ & $\begin{array}{l}\stackrel{\circ}{\circlearrowright} \\
\stackrel{\sim}{\sim}\end{array}$ & 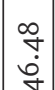 \\
\hline $\begin{array}{l}\dot{\omega} \\
\dot{m}\end{array}$ & & $\begin{array}{l}\stackrel{0}{0} \\
\dot{0} \\
\dot{0}\end{array}$ & $\begin{array}{l}\tilde{\hat{\dot{n}}} \\
\hat{n}\end{array}$ & $\begin{array}{l}\vec{y} \\
\dot{a} \\
\dot{v}\end{array}$ & & 号 & 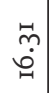 & 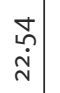 & & $\begin{array}{l}0 \\
0 \\
\dot{\alpha}\end{array}$ & 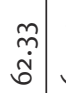 & 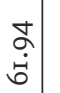 & $\underset{\stackrel{Y}{\dot{q}}}{ }$ & 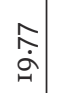 & $\begin{array}{l}\stackrel{\infty}{+} \\
\dot{J}\end{array}$ & $\begin{array}{l}\stackrel{0}{1} \\
\hat{\dot{n}}\end{array}$ \\
\hline $\begin{array}{c}\stackrel{\infty}{\llcorner} \\
\dot{m} \\
\dot{m}\end{array}$ & & $\begin{array}{l}\hat{\mathfrak{o}} \\
\stackrel{\sim}{+}\end{array}$ & $\begin{array}{l}\stackrel{\circ}{a} \\
\dot{\hat{n}} \\
\stackrel{n}{n}\end{array}$ & $\begin{array}{c}\mathcal{N} \\
\stackrel{5}{m} \\
\stackrel{m}{n}\end{array}$ & & 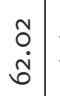 & $\begin{array}{l}\hat{b} \\
\dot{0} \\
\dot{0}\end{array}$ & 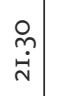 & & $\begin{array}{c}\hat{\infty} \\
\dot{N} \\
\alpha\end{array}$ & $\begin{array}{l}\hat{i} \\
\dot{0}\end{array}$ & $\begin{array}{l}a \\
\dot{a} \\
\dot{a}\end{array}$ & $\begin{array}{c}\stackrel{n}{\dot{q}} \\
\dot{f}\end{array}$ & $\begin{array}{l}\mathbb{J} \\
\dot{0} \\
\dot{0}\end{array}$ & $\begin{array}{l}\stackrel{\not}{+} \\
\dot{\exists}\end{array}$ & $\mid \begin{array}{c}\hat{o} \\
0 \\
0 \\
i n\end{array}$ \\
\hline $\begin{array}{l}i n \\
i=1\end{array}$ & & $\underset{m}{\stackrel{\oplus}{\oplus}}$ & 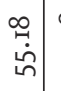 & 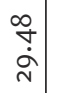 & & \begin{tabular}{l}
\multirow{2}{0}{} \\
$\dot{0}$ \\
0
\end{tabular} & $\begin{array}{l}\infty \\
\infty \\
0 \\
\dot{\omega}\end{array}$ & $\begin{array}{l}\stackrel{0}{0} \\
\stackrel{N}{N}\end{array}$ & & 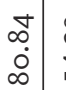 & $\begin{array}{l}\stackrel{\gamma}{ } \\
\dot{\sim}\end{array}$ & $\begin{array}{c}\hat{n} \\
\infty \\
\infty \\
i n\end{array}$ & $\begin{array}{l}\stackrel{\circ}{\dot{d}} \\
\dot{m}\end{array}$ & 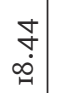 & $\underset{m}{\oplus}$ & 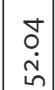 \\
\hline $\begin{array}{l}\stackrel{p}{+} \\
\dot{m}\end{array}$ & & $\begin{array}{l}\stackrel{Q}{\alpha} \\
\dot{\mathfrak{d}}\end{array}$ & $\begin{array}{c}\hat{n} \\
\hat{\tilde{n}}\end{array}$ & 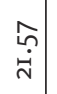 & & $\begin{array}{l}\infty \\
0 \\
\stackrel{\sim}{n} \\
\end{array}$ & 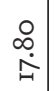 & $\begin{array}{l}\stackrel{\sim}{\tilde{j}} \\
\stackrel{N}{N}\end{array}$ & & 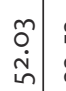 & $\begin{array}{l}\stackrel{m}{\hat{m}} \\
\stackrel{m}{m}\end{array}$ & $\begin{array}{c}\hat{0} \\
\dot{0}\end{array}$ & $\begin{array}{c}\stackrel{0}{\leftrightarrow} \\
\stackrel{\sim}{\sim}\end{array}$ & $\begin{array}{l}\infty \\
\stackrel{0}{0} \\
\stackrel{0}{0}\end{array}$ & 怘 & $\begin{array}{l}\stackrel{N}{\stackrel{\leftrightarrow}{m}} \\
\stackrel{m}{m}\end{array}$ \\
\hline 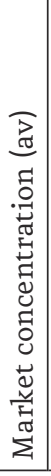 & 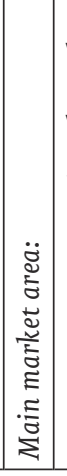 & 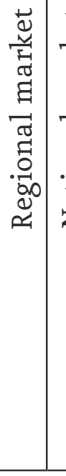 & 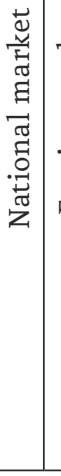 & 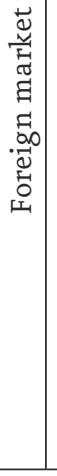 & 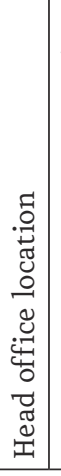 & 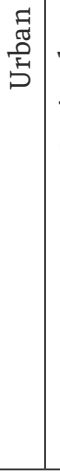 & 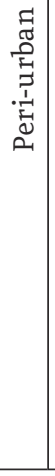 & 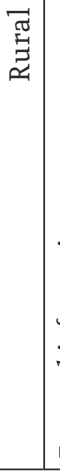 & 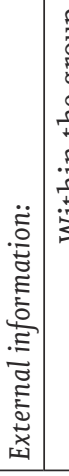 & 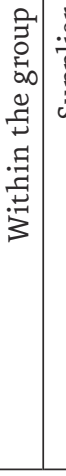 & 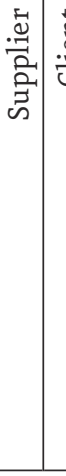 & 苟 & 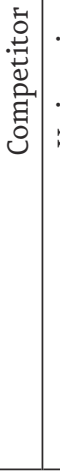 & 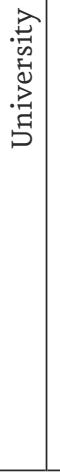 & 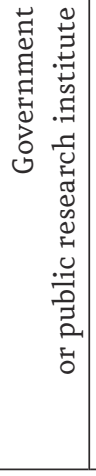 & 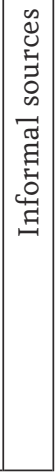 \\
\hline
\end{tabular}




\subsection{The dependent variables}

In our study, we have used two types of dependent variables. First, we build variables related to the different types of "standard" innovation (product, process and organizational) on which environmental innovations are embedded. Our objective was to identify in what way technical and organizational changes were complementary to environmental innovations, whether they affected work organization, production organization or firm's external relations. To conduct a more in-depth analysis of complementarity processes, we then decompose environmental innovation on the basis of the nine types of environmental impact. This has enabled us to highlight various forms of complementarity according to the type of environmental impact, and to analyze the influence of sectoral structures on these complementary processes.

- Variables of adoption of environmental, technical and organizational innovations

The probability of adopting an environmental innovation: The first dependent variable is the probability of adopting at least one environmental innovation. We estimate the probability for a firm to be, or not to be, eco-innovative by using the dichotomous variable that is equal to $\mathrm{I}$ in at least one of the nine modalities of eco-innovation (proposed by the CIS survey, see Table 2) is fulfilled, and to 0 otherwise.

The probability of adopting a product innovation: it is equal to I if the firm has introduced a product that is new to the firm and/or the market, 0 otherwise.

The probability of adopting a process innovation: it is equal to I if the firm has introduced an innovation in the production process, a new distribution method or support activity, 0 otherwise.

The probability of adopting an organizational innovation is estimated based on the answers to the three CIS survey questions concerning organizational change. The three variables are i) change in work organization (= I if the firm introduced new methods of work organization: new distribution of responsibilities/decision-making power among the employees, team work, 
decentralization, integration and empowering different departments in the company, training systems, etc., 0 otherwise); ii) change in the production organization (= I if the firm has introduced new decision-making methods: a new supply chain management system, reengineering of processes, knowledge management system, lean production, quality management system, etc.); iii) change in external relations (= I if the firm has introduced new methods of management of external relations with other companies or organizations: implementation for the first time of alliances, partnerships, of outsourcing or subcontracting projects; 0 otherwise)

- Variable of type of environmental impact

We then decompose the environmental innovations according to the type of environmental impact, to build nine dependent variables, to test the complementarities that arose between each type of environmental innovation and product innovation, process innovation and organizational change (i.e., change in the organization of production, work and external relations).

Those nine discrete and binary dependent variables are the following (see Table 2): the probability of reducing the use of materials per unit of output; the probability of reducing energy consumption per unit of output; the probability of reducing the $\mathrm{CO}_{2}$ emissions caused by the firm; the probability of substituting polluting materials; the probability of reducing soil, water or air pollution; the probability of recycling waste, water or raw materials; the probability of reducing the energy used per unit of output; the probability of reducing soil, water or air pollution during the consumption process; the probability of improved recycling of product after use.

Each of these nine explained variables is equal to $\mathrm{I}$ if the firm reports that it has introduced the environmental innovation, 0 otherwise. 


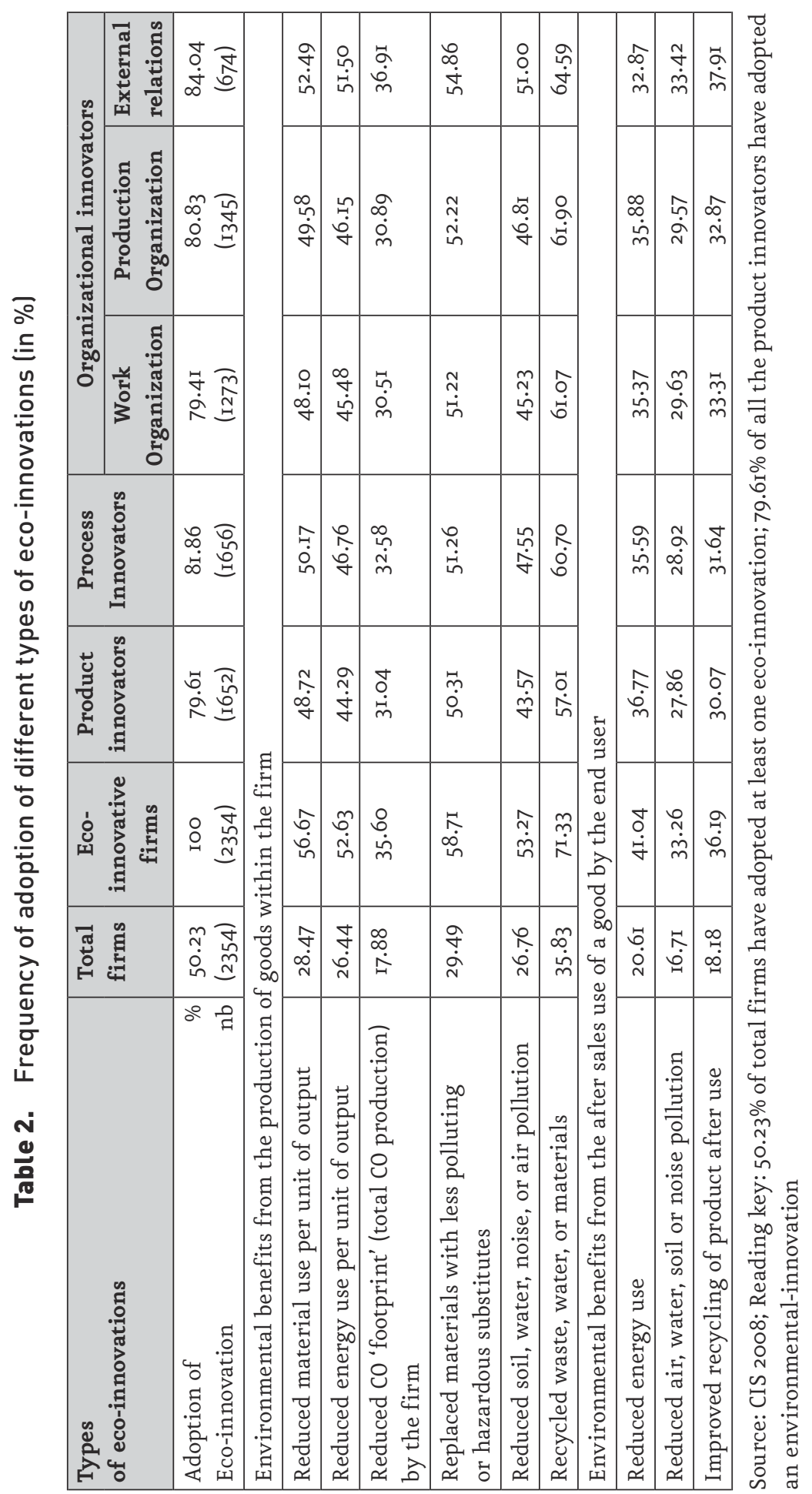




\subsection{The independent control variables}

We control the complementarity between two types of innovation by estimating bivariate probits, with a set of common control variables (Galia and Legros, 2004) (see table of variables description in appendix).

In line with the literature of economics of innovation and studies on ecoinnovation (Horbach et al., 2012; Galliano and Nadel, 2015), we have selected common control variables associated with traditional internal and external factors of technical, organizational and environmental innovations.

A first set of control variables related to variables such as the firm's size, its RER ratio or whether it belongs to a group are introduced to control for the firm's internal characteristics. A second set of variables aims to control the role of the firm's external environment. The sectoral environment is captured by the firm's sector and the adoption rate in the sector; the market environment by the market structure $\left(\mathrm{C}_{4}\right)$ and the main market area; the spatial environment by the location of the firm's head office. The information environment is another dimension of firms' external environment. We control with the sources of information for innovation, whether they came from industrial actors (customers, suppliers and competitors), or not (university, public research organization, or informal sources such as trade fairs, conferences or journals).

\section{THE RESULTS}

This section presents the results of the different complementarity tests. The results help to better understand the intra-organizational processes associated with eco-innovation in French industrial firms. In the first table of results (Table 3), we present all the coefficients between the dependent variables and the explanatory variables of each model (a firm's internal and external characteristics). These results are interesting in themselves, but are not the subject of this paper, which aims to study the process of complementarity. We will then present only the interaction term (rho), which reflects the degree of complementarity between environmental innovations and standard innovations (see Table 4 and following). We first examine the types of complementarity between technical change, 
organizational change and environmental innovation (4.I). We then deepen this general model by highlighting the complementarity according to the type of environmental impact of the innovation. The results help to better understand the processes of complementarity between each type of eco-innovation and changes in firm's organization (4.2).

\subsection{Complementarities between technical change, organizational change and environmental innovation: the general model}

The general model (Table 3) aims to test the existence of complementarity between the main types of innovation (product (MI), process $\left(\mathrm{M}_{2}\right)$ and organizational $\left(\mathrm{M}_{3}\right)$ ) and environmental innovation in the French industry. The first result of this general model reveals a positive interaction term (positive and significant $\mathrm{rho}^{3}$ ), which reflects the existence of a process of complementarity between the three types of innovation - whether product, process or organizational innovation - and environmental innovation. This result is expected, a priori, since environmental innovations are by definition embedded in a product, process or organizational innovation implemented within the firm. Less expected are the values of the interaction term, which indicate that the degree of complementarity varies according to the types of innovation. The results show that in the French industry the complementarity between organizational and environmental innovations is more intense $\left(\mathrm{M}_{3}, 0.659\right)$ than complementarity between environmental innovation and technical innovation. Thus, contrary to what we expected, the process of complementarity between technical and environmental innovations is significantly weaker, especially in the case of product innovations (Mr, 0.256). While the literature focuses primarily on analyzing the interactions between technical innovations and environmental innovations (see the literature on so-called "cleaner production" and "end-of-pipe" technical innovations, Rehfeld et al., 2007), these results reveal the particular importance of organizational processes in supporting environmental innovations.

3 The significance and value of the interaction term of each bivariate probit models gives the degree of complementarity (which will be important if the value of the interaction term approaches the value I) between technical and organizational innovation and environmental innovation. 


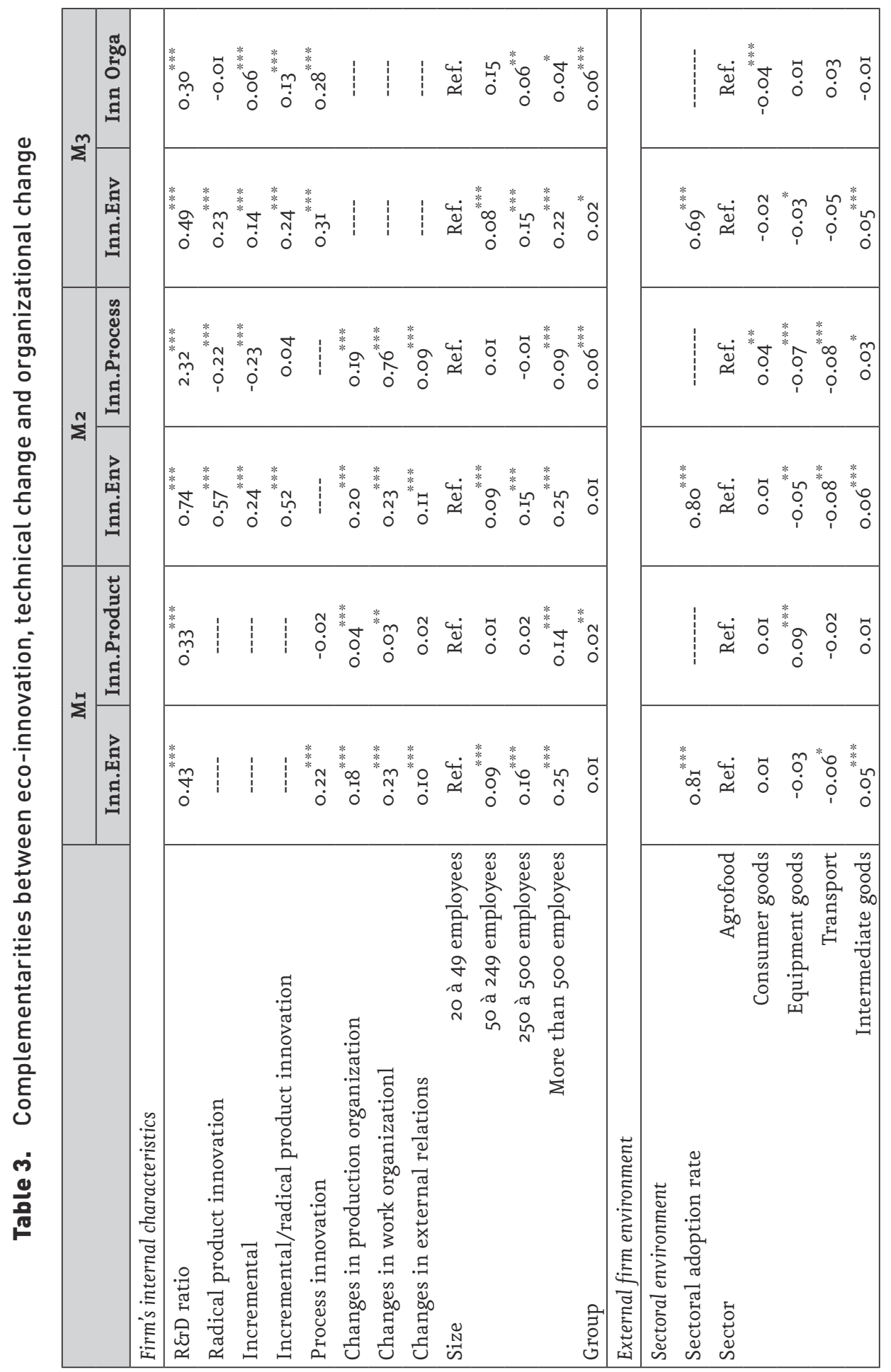




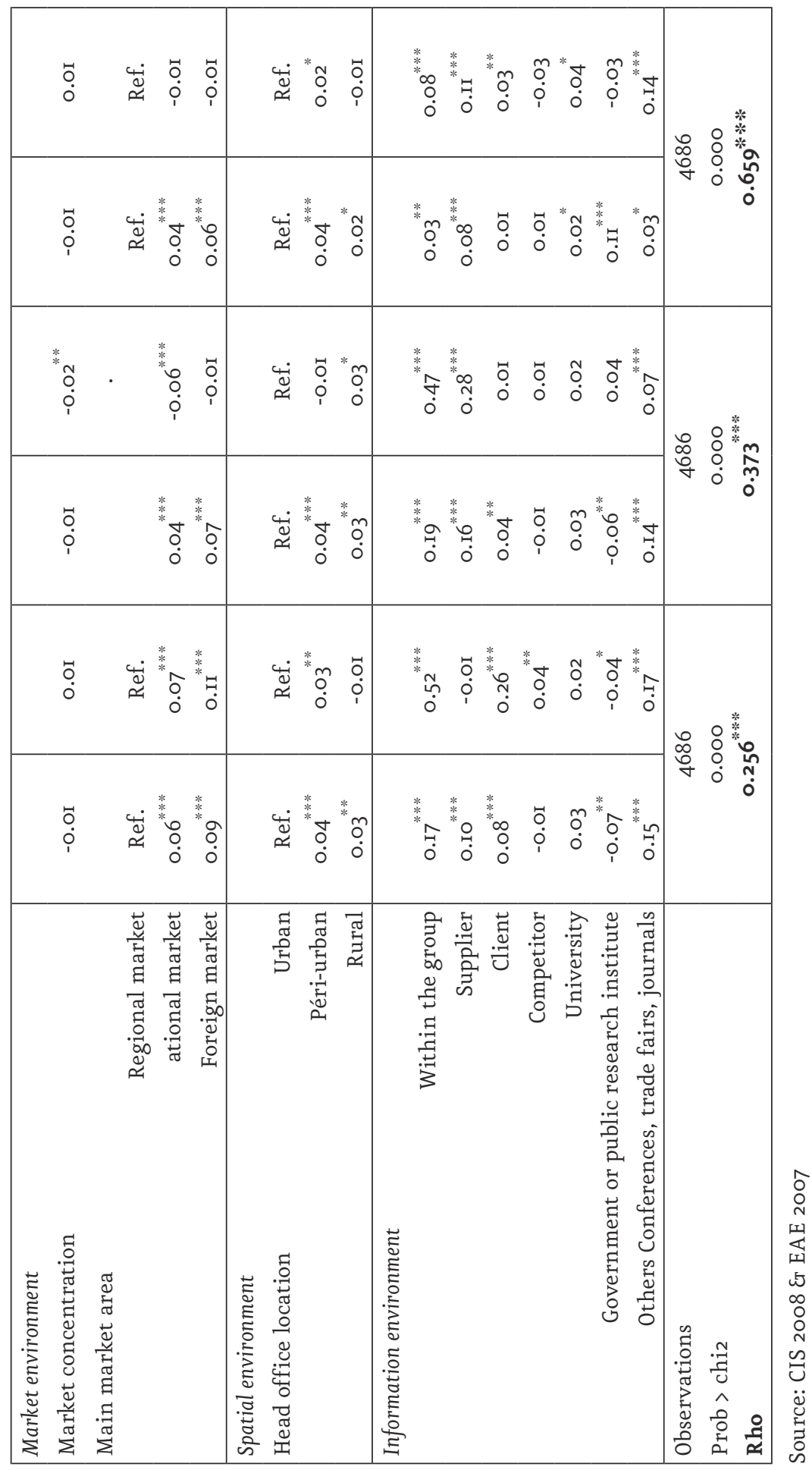


On the basis of this first result, the following model (see Table 4) enables us to analyze more in depth the interaction between organizational change and environmental innovations by distinguishing organizational innovation between innovations in the production, work and external relations organization ${ }^{4}$.

The results reveal that the three types of organizational change play a role in environmental innovation processes, but also that the development of complementarities is stronger between eco-innovation and changes in work organization (0.567) and production organization (0.528) than between eco-innovation and changes in the firm's external relations (o.423). They also highlight that the degree of complementarity varies according to industrial structures, and that each sector has specific ecoinnovation patterns. The transport industry is unique compared to other sectors because of the stronger complementarity between its environmental innovations and product innovations (o.6I7). This interaction is confirmed by the strong influence of changes in production organization. Environmental innovations in the intermediate goods and equipment goods industries tend to be process innovations and organizational innovations. The consumer goods industry has a similar profile with a high degree of complementarity between eco-innovation and changes in work organization (o.668). The agrofood industry has a specific profile, marked by product innovations and, especially, organizational innovations, with a higher than average interaction term between changes in external relations and eco-innovation (0.55I).

Concerning the common control variables, they confirm the role of a firm's internal resources, as well as the influence of external factors related to sectoral, market, spatial and informational environments. However, as our focus is on studying complementarity, we will not further discuss the interactions between these independent control variables and the explained variables 5 .

4 Even though we have presented the whole model so far, we present only the interaction term (rho), which measure the degree of complementarity between each type of innovation and environmental innovation.

5 For a deeper presentation of the diversity of factors influencing eco-innovation in French industry, see Galliano and Nadel (2015). 
Table 4. Environnemental innovation and sectoral structures

\begin{tabular}{|c|c|c|c|c|c|c|}
\hline \multirow[b]{2}{*}{ Sector } & \multirow{2}{*}{$\begin{array}{c}\text { Product } \\
\text { Innovation }\end{array}$} & \multirow[b]{2}{*}{$\begin{array}{c}\text { Process } \\
\text { Innovation }\end{array}$} & \multicolumn{4}{|c|}{ Organizational innovation } \\
\hline & & & $\begin{array}{c}\text { Total } \\
\text { O.I }\end{array}$ & Production & Work & $\begin{array}{l}\text { External } \\
\text { relations }\end{array}$ \\
\hline Agribusiness & $0.414^{* * *}$ & $0.215^{* * *}$ & $0.696 * * *$ & $0.604^{* * * *}$ & $0.593^{* * *}$ & $0.55^{* * *}$ \\
\hline $\begin{array}{l}\text { Consumer } \\
\text { goods }\end{array}$ & $0.195^{* * *}$ & $0.506 \% * *$ & $0.783^{* * *}$ & $0.566 * * *$ & $0.668 * * *$ & $0.516 * * *$ \\
\hline $\begin{array}{l}\text { Equipment } \\
\text { goods }\end{array}$ & O.II9* & $0.283^{* * *}$ & $0.633^{* * *}$ & $0.566 * * *$ & $0.571^{* * *}$ & $0.303^{* * * *}$ \\
\hline Transports & $0.617^{* * *}$ & $0.268 *$ & $0.430 \% * *$ & $0.549^{* * *}$ & $0.347^{* * *}$ & $0.215^{*}$ \\
\hline $\begin{array}{l}\text { Intermediate } \\
\text { goods }\end{array}$ & $0.245^{* * *}$ & $0.380 * * *$ & $0.666 * * *$ & $0.516 \% *$ & $0.564 * * *$ & $0.43^{* * * *}$ \\
\hline Total & $0.256 * * *$ & $0.373^{* * *}$ & $0.659 * * *$ & $0.528 * * *$ & $0.567^{* * *}$ & $0.423^{* * *}$ \\
\hline
\end{tabular}

Sources: CIS 2008 \& EAE 2007

Reading Key: For firms in the food sector, the interaction term between the probability to innovate in products and the probability of adopting an environmental innovation is 0.414 ***

\subsection{Types of eco-innovation and sectoral structure: a diversity of complementarity mechanisms}

Beyond the general model, we aim to analyze the processes of complementarity according to the type of environmental impact, and particularly to distinguish eco-innovations whose environmental benefit is generated during the production processes, from those whose benefits occur during the consumption of the goods (or services) supplied by the firm (Table 5). These results will be deepened by an analysis of complementarity according to sectors in order to highlight the common mechanisms and sectoral specificities (Tables 6 and 7 ).

Overall, the first results (Table 5) confirm the high degree of complementarity between eco-innovation and organizational innovation. Indeed, the coefficients of interaction between environmental innovation and organizational change are higher than those between environmental innovation and technical innovations, whatever the type of eco-innovation.

Organizational innovations tend to be adopted while eco-innovations occurred in the production process. Recycling of waste, water and materials, the most commonly adopted type of eco-innovation is associated with 
the strongest complementarities with organizational innovation (0.512, Table 5). More specifically, we observe that recycling practices demonstrates more complementarity with changes in internal organization (production and work organization), respectively, 0.428 and 0.454 , than with changes in external relations (0.302). Yet, recycling practices - which are associated with circular economy and industrial ecology - are often related to changes in external relations. These results show that circular economy processes not only affect changes in external relations, but also changes in a firm's internal organization.

Then, the results reveal the complementarity between organizational changes and eco-innovations expected to replace materials with less hazardous substitutes $(0.420)$ or those intended to reduce the consumption of materials and energy per unit of output (0.4OI and 0.396). These findings are in line with other studies that show that - beyond factors related to cost and regulation - some environmental innovations are specifically correlated with organizational changes (Antonioli et al., 2013; Hottenrot et al., 2016). Recycling processes are often interactive and carried out with other firms or consumers (Horbach et al., 20I2; Doran and Ryan, 20I6). Environmental innovations intended to reduce energy and material consumption, were adopted jointly with changes in work organization. Therefore, they are implemented as part of the reorganization or rationalization of relations between firms' units (Horbach et al., 2012 in the case of Germany).

Concerning product innovations, the results show their interaction with eco-innovations is weaker than those between eco-innovations and organizational innovations. Eco-innovations aimed at reducing $\mathrm{CO}_{2}$ emissions (0.079) or pollution (0.087) are embedded in process and organizational innovations more than in product innovations. Product innovations have a slightly higher degree of complementarity with eco-innovations whose benefits occur during the consumption process. This is particularly marked for the reduction of energy consumption per unit consumed (0.222) and for post consumption recycling (0.15I). Thus, although the degree of complementarity between environmental and product innovations is lower than that between eco-innovations and organizational change, the results show a particularly high degree of complementarity between product innovations and environmental innovations aimed at replacing materials with less polluting or hazardous substitutes (0.193) and eco-innovations for waste recycling (0.177). 


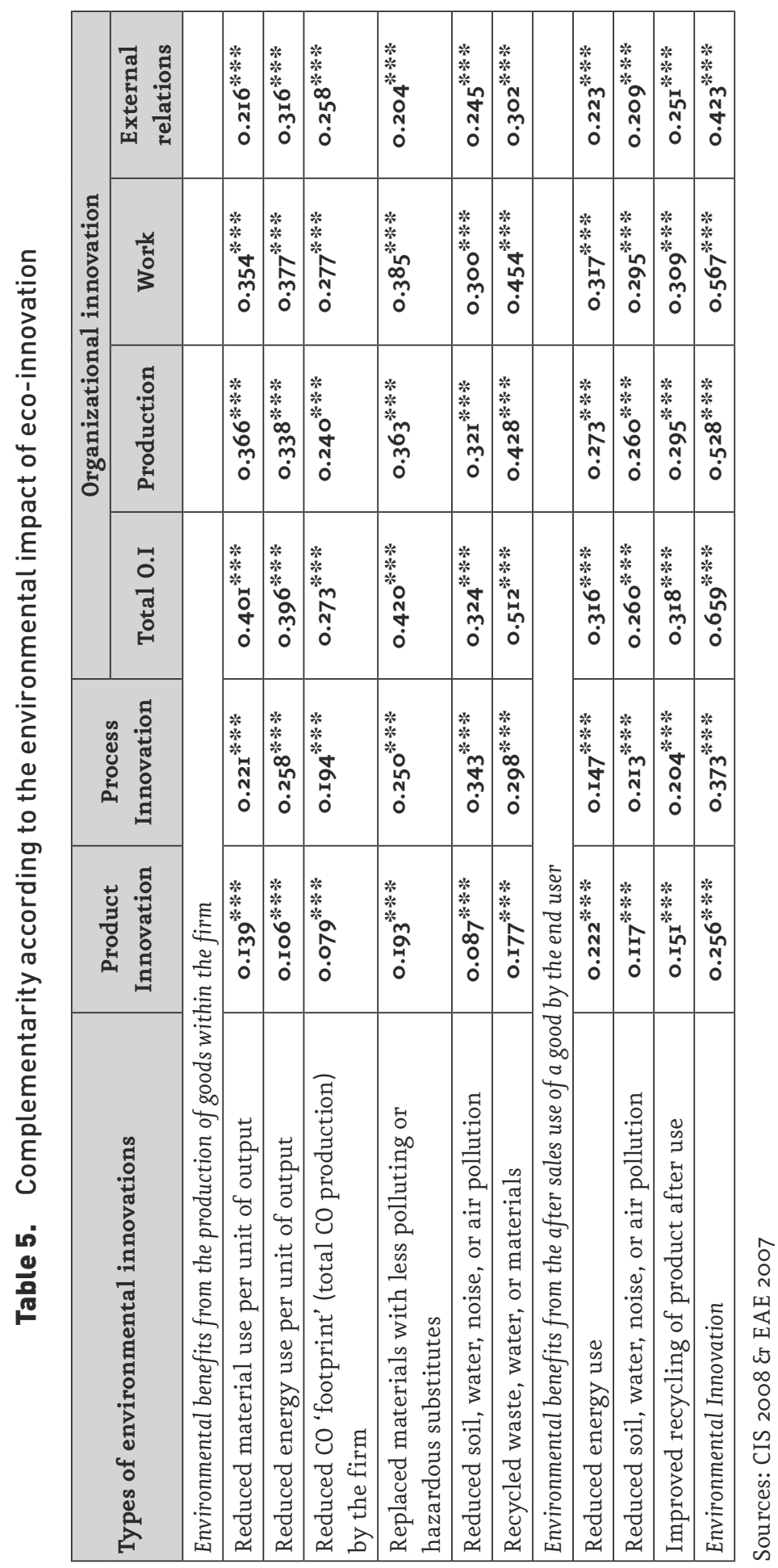


Regarding process innovations, the complementary processes are more production-oriented than consumer-oriented (except for innovations aimed at reducing the use of materials per unit of output). These complementarities between environmental innovation and process innovation are particularly strong for innovations aiming at reducing soil, water and air pollution (0.343), and innovations for recycling (0.298) and reducing energy use per unit produced (0.258).

The profiles of complementarities sector (Tables 6 and 7 ) help to deepen the analysis of sectoral patterns. Regarding the agrofood industry, with the exception of the high complementarity between product innovations and environmental innovations aimed at replacing polluting materials, environmental innovation is strongly embedded in organizational innovation. The results tend to show that the complementarity between environmental innovation and organizational innovation is overall higher in agribusiness than in other sectors: results highlight complementarity rates with organizational innovations often higher in agribusiness than the average of all sectors: as for the reduction of material (0.498) and energy (o.624) per unit of output, or reduction of energy consumption (0.487) and pollution ( 0.443 ) during the consumption process. This complementarity between environmental innovation and organizational innovation is carried on by both changes in work and production organization, but also by changes in external relations, with an interaction term often higher than ones of the others sectors. Complementarity between environmental innovation and changes in external relations in agribusiness is particularly high in the case of eco-innovations expected to reduce the energy consumption per unit during the production process (0.509) and during the consumption process (0.449). 


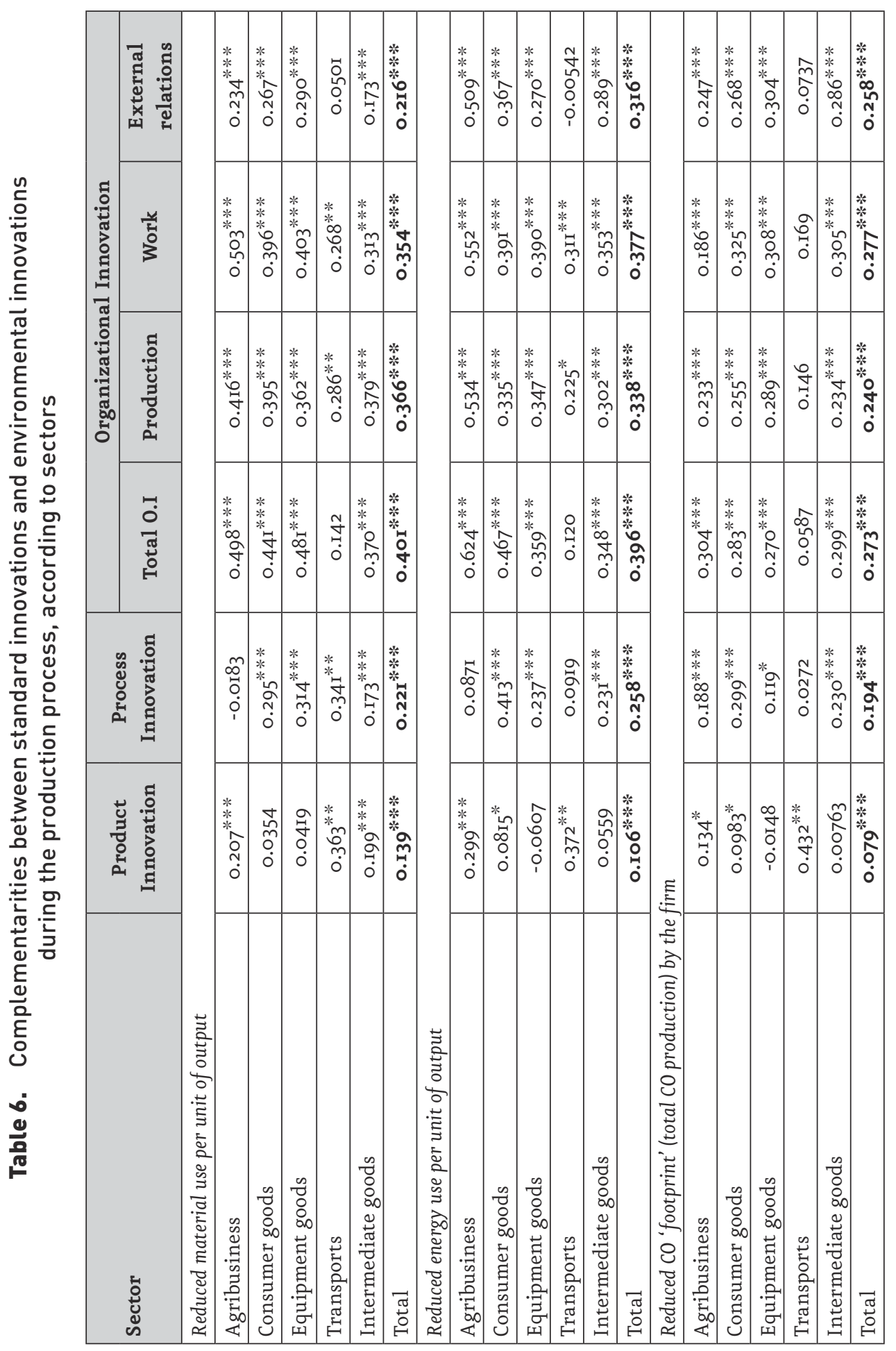




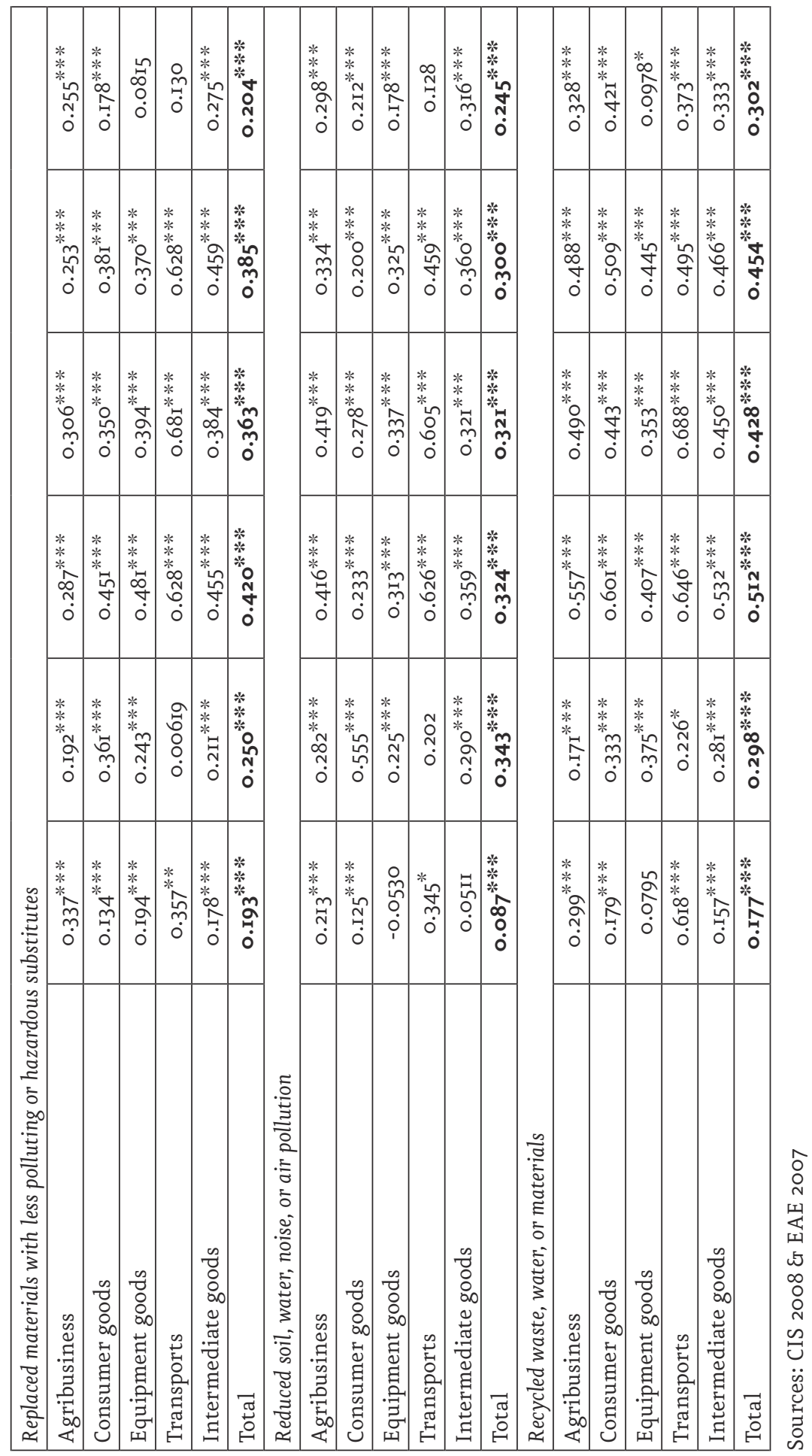




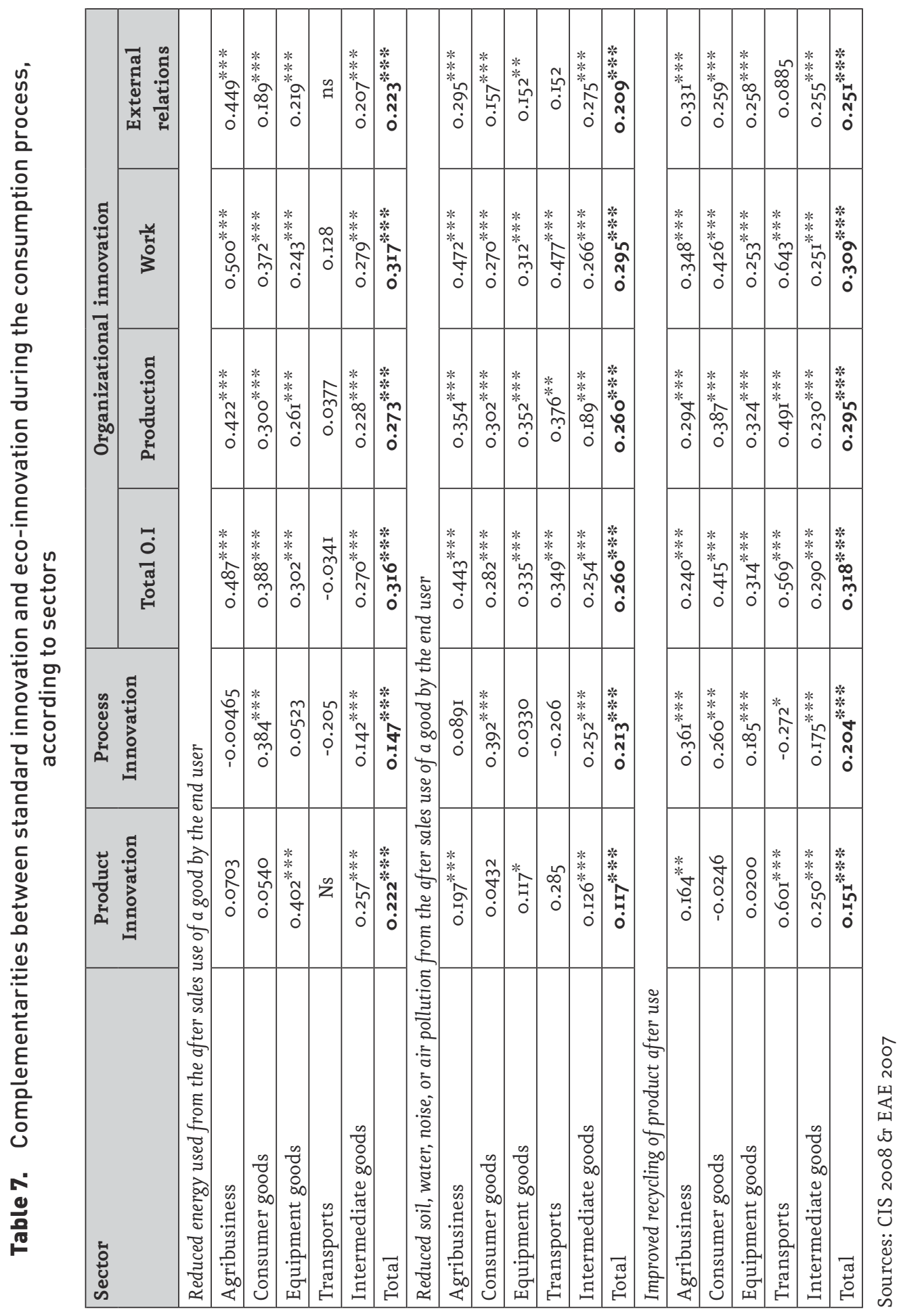


Among other sectors, the specificity of the transport industry is related to the weight of complementarities between eco-innovations and product innovation. Complementarities with process innovations are often weaker in the transport industry, except for reducing the use of materials per unit produced. Firms in the consumer goods sector carry on their ecoinnovations on organizational change as well as on process innovations, particularly in their efforts to reduce pollution and their consumption of energy and materials during the production process. This industry is the one that relies the most on process innovation to improve the environmental impact (energy consumption, pollution and recycling) of their products during the consumption process. Firms' behavior in the equipment and intermediate goods industries are very close to those observed in the general model and the average profile of French industrial firms. Their environmental innovations are mainly carried on organizational innovations, whatever the type of eco-innovation. The specificity of firms in the intermediate goods sector, which mostly consists of polluting industries (chemicals, plastics, metal, etc.), lies in the fact that they adopt various technical and organizational innovations in order to improve the environmental impact during the consumption of their products, which, de facto, are intermediate goods for other industries.

\section{DISCUSSION}

The literature highlights that, by definition, an environmental innovation is a process-, product- or organizational innovation that leads to an environmental benefit. This implies a complementarity process between environmental innovation and technical or organizational changes. This complementarity has never been estimated. The method used here makes it possible to evaluate the intensity of the complementarity process, in a comparative way, between the different types of innovation.

The results highlight the intensity of complementarity processes between environmental innovation and organizational innovation. The literature mainly shows the fundamental changes brought about by technological innovation and transformation in terms of processes (cf. the debate between end of pipe vs. cleaner production), as well as in the product design (eco-conception, green products...). Fewer studies focus on the 
modes of coordination between actors and between firms' various units, and more fundamentally, on organizational dynamics. Our results show that in the French production system, organizational innovations do favor the environmental performance of French industrial firms.

This strong complementarity between the adoption of new environmental practices and all types of organizational changes tends to reveal that circular economy dynamics affect not only changes in external relations, but also have an influence on changes in firms' internal organization, on work and production organization.

\section{CONCLUSION}

The literature on complementarity suggests that firms may have more effective uses for some technological practices if they adjust organizational design to complement new practices. Mobilizing the analytical framework of the complementarity makes it possible to reveal that the new environmental practices implemented by firms are highly complementary to organizational changes rather than with new technical practices (adoption of new products or processes). This analysis has enabled us to reveal the diversity in the forms of complementarity between the development of environmental innovations and organizational changes according to the types of environmental impact (savings energy, recycling, etc.).

Thus, one key result of this analysis is the identification of the major influence of organizational change dynamics on environmental innovation processes, which goes counter to a technical vision of environmental innovations which tends to associate new environmental practices with new green products or processes.

We contribute to the analysis of eco-innovation and complementarities by highlighting the intensity of complementarity forms. The comparative approach makes it possible to put in perspective the different types of complementarity, which rely on technical changes and changes in work organization and management practices, but also on changes in relations with external partners. Beyond technical changes, we show the role of organizational arrangements, learning processes and the rationalization of management forms. In terms of managerial and public policy, our study 
recommends promoting the adoption of environmental management practices and corporate social responsibility processes. Finally, the question of organizational design must be better associated with the issue of environmental performance and ecological transition of firms and industries.

\section{REFERENCES}

ALONSO UGAGLIA, A., FERRU, M., GUIMOND, B. (20I6), "Stratégies et trajectoires environnementales des établissements de Poitou-Charentes ", Revue d'économie industrielle, vol. I53, pp. 9-45.

ANTONIOLI, D., MANCINELLI, S., MAZZANTI, M. (2013), "Is environmental innovation embedded within high-performance organisational changes? The role of human resource management and complementarity in green business strategies ", Research Policy, vol. 42, $\mathrm{n}^{\circ}$ 4, pp. 975-988.

ANTONIOLI, D., NICOLLI, F., MAZZANTI, M., GILLI, M. (20I3), «Information Technology, Environmental Innovations and Complementarity Strategies ", Quaderno DEM, $13 / 2013$.

ANTONIOLI, D., MAZZANTI, M. (2009), « Techno-organisational strategies, environmental innovations and economic performances. Micro-evidence from an SMEbased industrial district ", Journal of Innovation Economics and Management, vol. 3, pp. I45-168.

ARORA, A. (1996), "Testing for complementarities in reduced-form regressions: A note ", Economics Letters, vol. 50, pp. 5I-55.

ARORA, A., GAMBARDELLA, A. (1994), "The changing technology of technological change: general and abstract knowledge and the division of innovative labour ", Research Policy, vol. 23, pp. 523-532.

ARUNDEL, A., KEMP, R., PARTO, S. (2007), " 2I Indicators for environmental innovation: What and How to measure ", in D. Marinova, D. Annandale, J. Phillimore, International handbook on environment and technology management (pp. 324-339), Cheltenham, Edward Elgar.

ATHEY, S., STERN, S. (I998), « An empirical framework for testing theories about complementarity in organizational design ", Nber working paper series, 6600.

BATTISTI, G., STONEMAN, P. (2003), "Inter- and intra-firm effects in the diffusion of new process technology ", Research Policy, vol. 32, pp. I64I-I655.

BATTISTI, G., STONEMAN, P. (20I0), « How innovative are UK firms? Evidence from the fourthUK community innovation survey on synergies between technological and organizational innovations ", British Journal of Management, vol. 2I, pp. 1987-206.

BECKER, M., LAZARIC, N. (2003), " The influence of knowledge in the replication of routines ", Économie appliquée, vol. 3, pp. 65-94.

BENGHOZI, P. J. (200I), "Relations interentreprises et nouveaux modèles d'affaires". Revue économique, vol. 52, pp. 165-190.

BOCQUET, R., BROSSARD, O., SABATIER, M. (2007), "Complementarities in organizational design and the diffusion of information technologies: An empirical analysis ", Research Policy, vol. 36, n 3, pp. 367-386. 
BROUILLAT, E., OLTRA, V. (20I2), « Extended producer responsibility instruments and innovation in eco-design: An exploration through a simulation model », Ecological Economics, vol. 83, pp. 236-245.

BRYNJOLFSSON, E., HITT, L. M. (2000), "Beyond computation: Information technology, organizational transformation and business performance ", The Journal of Economic Perspectives, vol. I4, pp. 23-48.

CAINELLI, G., MAZZANTI, M., MONTRESOR, S. (2012), "Environmental Innovations, Local Networks and Internationalization ", Industry and Innovation, vol. 19, pp. 697-734.

CHANDLER, A. (1962), Strategy and Structure. Chapters in the History of the Industrial Enterprise. Cambridge Mass., MIT Press.

DEBREF, R. (2016), " Pour une approche systémique de l'innovation “environnementale" ", Revue d'économie industrielle, vol. 155, pp. 7I-98.

DEL RIO, P., PENASCO, C., ROMERO-JORDAN, D. (20I5), "Distinctive Features of Environmental Innovators: An Econometric Analysis ", Business Strategy and the Environment, vol. 24, pp. 36I-385.

DELMAS, M., PEKOVIC, S. (2013), "Environmental standards and labor productivity: Understanding the mechanisms that sustain sustainability ", Journal of Organizational Behavior, vol. 34, pp. 230-252.

DORAN, J., RYAN, G. (20I6), "The Importance of the Diverse Drivers and Types of Environmental Innovation for Firm Performance ", Business Strategy and the Environment, vol. 25, pp. 73-I48.

EVANGELISTA, R., VEZZANI, A. (2012), " The impact of technological and organizational innovations on employment in European firms ", Industrial and Corporate Change, vol. 2I, $\mathrm{n}^{\circ} 4$, pp. 87I-899.

FRONDEL, M., HORBACH, J., RENNINGS, K, (2007), « End-of-pipe or cleaner production? An empirical comparison of environmental innovation decisions across OECD countries ", Business Strategy and the Environment, vol. I6, pp. 571-584.

GALIA, F., LEGROS, D. (2004), "Complementarities between obstacles to innovation: evidence from France ", Research Policy, vol. 33, pp. II85-II99.

GALLIANO, D., NADEL, S. (2015), "Firms' Eco-innovation Intensity and Sectoral System of Innovation: The Case of French Industry ", Industry and Innovation, vol. 22, pp. 467-495.

GALliANO, D., OROZCO, L. (2013), "New Technologies and Firm Organization: The Case of Electronic Traceability Systems in French Agribusiness ", Industry and Innovation, vol. 20, pp. 22-47.

GILLI, M., MANCINELLI, S., MAZZANTI, M. (20I4), "Innovation complementarity and environmental productivity effects: Reality or delusion? Evidence from the EU ", Ecological Economics, vol. Io3, pp. 56-67.

GREENAN, N, (2003), "Organisational change, technology, employment and skills: an empirical study of French manufacturing ", Cambridge Journal of Economics, vol. 27, pp. 287-316.

GREENE, W. (2003), Econometric Analysis. Englewood Cliffs, Prentice Hall.

HERVAS-OLIVIER, J.-L., SEMEPERE-RIPOLL, F., BORONAT-MOLL, C. (2OI2), "Process Innovation Objectives and Management Complementarities: Patterns, Drivers, Co-Adoption and Performance Effects ", UNU-MERIT Working Paper, 20I2-5I. 
HOJNIK, J., RUZZIER, M. (20I6), "What drives eco-innovation? A review of an emerging literature ", Environmental Innovation and Societal Transitions, vol. I9, pp. 3I-4I.

HODSGON, G., KNUDSEN, T. (2007), "Firm-Specific Learning and the Nature of the Firm: Why Transaction Costs May Provide an Incomplete Explanation ", Revue économique, vol. 58, pp. 33I-350.

HORBACH, J., OLTRA, V., BELIN, J. (2013), « Determinants and specificities of eco-innovations compared to other innovations: an econometric analysis for the French and German industry based on the community innovation ", Industry and Innovation, vol. 20, pp. 523-543.

HORBACH, J, (2008), " Determinants of Environmental Innovations, New Evidence From German Panel Data Sources ", Research Policy, vol. 37, pp. I63-173.

HORBACH, J., RAMMER, C., RENNINGS, K. (20I2), " Determinants of eco-innovations by type of environmental impact: The role of regulatory push-pull, technology push and market pull ", Ecological Economics, vol. 78, pp. II2-I22.

HOTTENROT, H., REXHAUSER, S., VEUGELERS, R. (20I6), "Organisational change and the productivity effects of green technology adoption ", Resource and Energy Economics, vol. 43, pp. 172-I94.

LAURSEN, K., MAHNKE, V. (200I), " Knowledge strategies, firm types, and complementarity in human-resource practices ", Journal of Management and Governance, vol. 5, pp. I-27.

MAZZANTI, M., ZOBOLI, R. (2008), "Complementarities, firm strategies and environmental innovations: empirical evidence for a district based manufacturing system ", Environmental Sciences, vol. 5, pp. 17-40.

MILGROM, P., ROBERTS, J. (I990), « The economics of modern manufacturing: technology, strategy and organization », American Economic Review, vol. 80, pp. 5II-528.

MILGROM, P., ROBERTS, J. (I995), "Complementarities and fit strategy, structure, and organizational change in manufacturing ", Journal of Accounting and Economics, vol. I9, pp. 179-208.

MILGROM, P., ROBERTS, J. (I997), Economics, organisation and management, Bruxelles, De Boeck.

MILGROM, P., SHANNON, C, (1994), "Monotone Comparative Statics ", Econometrica, vol. 62, pp. 157-I80.

NADEL, S., (2013), "La responsabilité sociale de l'entreprise comme forme de justification : quels impacts sur le travail ? " Revue Française de Socio-Économie, n ${ }^{\circ}$ II, pp. 165-179.

REHFELD, K., RENNINGS, K., ZIEGLER, A. (2007), "Integrated product policy and environmental product innovations: An empirical analysis ", Ecological Economics, vol. 6, pp. 9I-Ioo.

RENNINGS, K. (2000). "Redefining innovation: eco-innovation and the contribution from ecological economics ", Ecological Economics, vol. 32, pp. 319-332.

RENNINGS, K., ZIEGLER, A., ANKELE, K., HOFFMANN, E. (2006), " The influence of different characteristics of the EU environmental management and auditing scheme on technical environmental innovations and economic performance", Ecological Economics, vol. 57, pp. 45-59.

ROBERTSON, J., BARLING, J. (2013), " Greening organizations through leaders' influence on employees' pro-environmental behaviors ", Journal of Organizational Behavior, vol. 34, pp. 176-194. 
ROTHENBERG, S., ZYGLIDOPOULOS, S. (2007), " Determinants of Innovation Adoption in the Printing Industry: the Importance of Task Environment », Business Strategy and the Environment, vol. I6, pp. 39-49.

SAPPRASERT, K., CLAUSEN, T.. (20I2) "Organizational innovation and its effects", Industrial and Corporate Change, vol. 2I, $\mathrm{n}^{\circ}$ 5, pp. 1283-1305.

TOPKIS, D. (1998), Supermodularity and complementarity, Princeton, Princeton University Press.

TOPKIS, D. (1995), "The Economics of Modern Manufacturing: Comment », American Economic Review, vol. 85, pp. 99I-996.

VAN DEN BERGH, J.C.J.M., TRUFFER, B., KALLIS, G. (20II). « Environmental Innovation and Societal Transitions: Introduction and Overview ", Environmental Innovation and Societal Transitions, vol. I, pp. I-23.

WAGNER, M. (2007), "On the relationship between environmental management, environmental innovation and patenting: evidence from German manufacturing firms ", Research Policy, vol. 36, pp. 1587-1602.

WAGNER, M. (2008), " Empirical influence of environmental management on innovation: evidence from Europe ", Ecological Economics, vol. 66, pp. 392-402.

WAGNER, M., LLERENA, P. (2OII), «Eco-innovation through integration, regulation and cooperation: comparative insights from case studies in three manufacturing sectors ", Industry and Innovation, vol. 18, pp. 747-764.

WOOLDRIDGE, J. (2002), Econometric Analysis of Cross Section and Panel Data, Cambridge Mass., MIT Press. 


\section{APPENDIX. VARIABLES DESCRIPTION}

\begin{tabular}{|c|c|}
\hline Variable & Description \\
\hline RED ratio & Logarithm of the ratio RerD expenses on sales \\
\hline $\begin{array}{r}\text { Product Innovation: } \\
\text {-Radical } \\
\text { - Incremental } \\
\text {-Radical / } \\
\text { Incremental }\end{array}$ & $\begin{array}{l}=\mathrm{I} \text { if the the firm developed only innovation(s) new } \\
\text { for the market, } 0 \text { otherwise } \\
=\mathrm{I} \text { if the the firm developed only innovation(s) new only } \\
\text { for the firm, } 0 \text { otherwise } \\
=\mathrm{I} \text { if the firm develop both innovations new for the firm } \\
\text { and innovations new for the market, } 0 \text { otherwise }\end{array}$ \\
\hline Process innovations & $=\mathrm{I}$ if the firm introduces a process innovation, 0 otherwise \\
\hline $\begin{array}{r}\text { Changes in: } \\
\text {-Labour } \\
\text { organisation }\end{array}$ & $\begin{array}{l}=\mathrm{I} \text { if introduction of new methods of organising work } \\
\text { responsibilities and decision making, i.e. first use of } \\
\text { a new system of employee responsibilities, team work, } \\
\text { decentralisation, integration or de-integration of departments, } \\
\text { education/training systems, etc, } 0 \text { otherwise }\end{array}$ \\
\hline $\begin{array}{l}\text {-Production } \\
\text { organisation }\end{array}$ & $\begin{array}{l}=\mathrm{I} \text { if introduction of new business practices for organising } \\
\text { procedures, i.e supply chain management, business } \\
\text { re-engineering, knowledge management, lean production, } \\
\text { quality management, etc., } 0 \text { otherwise }\end{array}$ \\
\hline $\begin{array}{l}\text {-External } \\
\text { relations }\end{array}$ & $\begin{array}{l}=\mathrm{I} \text { if introduction of new methods of organising external } \\
\text { relations with other firms or public institutions, i.e. first use } \\
\text { of alliances, partnerships, outsourcing or sub-contracting, etc, } \\
0 \text { otherwise }\end{array}$ \\
\hline Size & $\begin{array}{l}\text { Qualitative variable with } 4 \text { modalities: } 20 \text { to } 49 \text { employees } \\
\text { reference; } 50 \text { to 249; } 250 \text { to } 499 \text {; and more than } 500\end{array}$ \\
\hline Group & $=\mathrm{I}$ if the firm is the subsidiary of a group, 0 if independent \\
\hline
\end{tabular}




\begin{tabular}{|c|c|}
\hline Variable & Description \\
\hline $\begin{array}{l}\text { Information sources: } \\
\text { within the group }\end{array}$ & $\begin{array}{l}\text { = I if the firm has identify information sources that provided } \\
\text { information for new innovation projects or contributed } \\
\text { to the completion of existing innovation projects: } \\
\text { from other enterprises within the group, } 0 \text { otherwise }\end{array}$ \\
\hline Supplier & $\begin{array}{l}\text { from suppliers of equipment, materials, components, } \\
\text { or software, } 0 \text { otherwise }\end{array}$ \\
\hline Client & from clients or customers, 0 otherwise \\
\hline Competitor & $\begin{array}{l}\text { from competitors or other enterprises in the sector, } \\
0 \text { otherwise }\end{array}$ \\
\hline University & $\begin{array}{l}\text { from universities or other higher education institutions, } \\
0 \text { otherwise }\end{array}$ \\
\hline $\begin{array}{r}\text { Public Research } \\
\text { institute }\end{array}$ & $\begin{array}{l}\text { from government or public research institutes, } \\
0 \text { otherwise }\end{array}$ \\
\hline Other & $\begin{array}{l}\text { from conferences, trade fairs, exhibitions, scientific } \\
\text { journals and trade/technical } \\
\text { publications, professional and industry associations, } \\
0 \text { otherwise }\end{array}$ \\
\hline $\begin{array}{l}\text { Sectoral adoption } \\
\text { rate }\end{array}$ & $\begin{array}{l}\text { Logarithm of the average rate of eco-innovation adoption } \\
\text { by the firms of the same sector level } 3 \text { of Naf } 2008 \text { rev.2 }\end{array}$ \\
\hline $\begin{array}{l}\text { Market } \\
\text { concentration }\end{array}$ & $\begin{array}{l}\text { Logarithm of the } \mathrm{C} 4 \text { concentration ratio: cumulated market } \\
\text { shares of the first four firms in the sector }\end{array}$ \\
\hline $\begin{array}{l}\text { Main market } \\
\text { location }\end{array}$ & $\begin{array}{l}\text { Qualitative variable with } 3 \text { modalities: Regional market } \\
\text { reference; National market; Foreign market }\end{array}$ \\
\hline Head office location & $\begin{array}{l}\text { Qualitative variable with } 3 \text { modalities for the location } \\
\text { of the firm's head office: Urban area reference; } \\
\text { Peri-urban area; Rural area }\end{array}$ \\
\hline
\end{tabular}

